\title{
Petrol Fiyatlarının Makro Ekonomi Üzerindeki Etkisi-Ülke Karşılaştırmaları İle Panel Veri Analizi
}

\author{
Mehmet Alagöz $^{1}$, Nur Dilbaz Alacahan², Yağmur Akarsu ${ }^{3}$ \\ ${ }^{1}$ Selçuk Üniversitesi İktisadi ve İdari Bilimler Fakültesi İktisat Bölümü \\ ${ }^{2}$ Çanakkale Onsekiz Mart Üniversitesi Biga Uygulamalı Bilimler Yüksek Okulu Banka ve Finans Bölümü \\ ${ }^{3}$ Çanakkale Onsekiz Mart Üniversitesi Gökçeada Meslek Yüksek Okulu Yönetim ve Organizasyon Bölümü
}

\begin{abstract}
Özet
Bu çalışmada, OECD’nin (Organisation for Economic Cooperation and Development) 12 Aralık 2016 tarihli "Küresel Kalkınma Hakkında Perspektifler 2017" adıyla yayınlanan raporunda adı geçen Türkiye, Çin, Güney Afrika, Meksika, Kolombiya, Kosta Rika, Endonezya ve Kazakistan'ın 2030 yılında yüksek gelirli ülkeler grubunda olacağının belirtilmesi üzerine, ekonomik düzeyde birbirine benzer bu ülkelerde petrol fiyatlarının makro ekonomik değişkenlere etkileri araştırılmaya çalışılmıştır. Veriler yıllık bazda olup 1980-2016 dönemini kapsamaktadır. Veriler, Dünya Bankası’ndan alınmıştır. Petrol fiyatlarının, cari açık ve enflasyon üzerindeki etkisini araştırmak amacıyla panel veri analizi yapılmıştır. Yapılan çalışmanın sonucuna göre, ham petrol fiyatında bir dolarlık artış, incelenen ülkeler genelinde enflasyon üzerinde \%0.04 artışa sebep olmaktadır. Ham petrol fiyatında artış, cari denge üzerinde negatif bir etki yaparak cari açık yönünde tesir etmektedir. Petrol fiyatında bir birim artış, cari denge üzerinde-\$30.833.384,19 etki oluşturmaktadır.
\end{abstract}

Anahtar Kelimeler: Petrol Fiyatları, Cari Açık, Enflasyon, Panel Veri Analizi.

\section{Effects of Petroleum Prices on Macro Economy-Country Comparative with Panel Data Analysis}

\section{Abstract}

In this study, it was attempted to investigate the effects of oil prices on macroeconomic variables in these countries which are similar in economic level upon, specifying Turkey, China, South Africa, Mexico, Colombia, Costa Rica, Indonesia and Kazakhstan mentioned in the report of the OECD (Organization for Economic Cooperation and Development) published in the December 12, 2016, titled as "Perspectives on Global Development 2017 " as will be in the group of high-income countries in 2030. The data are on an annual basis and cover the period 1980-2016. These data are taken from World Bank website. Panel data analysis was conducted to investigate the effects of oil prices on economic growth, current account deficit and inflation. According to the results of the study, A dollar increase in Crude Oil price caused a $0.04 \%$ increase in inflation across the countries examined. Increase in Crude Oil price, affecting as current account deficit by making a negative impact on the current account balance. A unit increase in oil prices is affecting the current account balance - $\$$ $30,833,384.19$.

Keywords: Oil Prices, Current Account Deficit, Inflation, Panel Data Analysis.

\section{Giriş}

Yenilenemeyen enerji kaynaklarının en önemlilerinden biri petroldür. Petrol, dünya ekonomisinde sadece ham madde olarak değil aynı zamanda özellikle tekstilde, savunma sanayide ve ulaştırma sektörlerinde ara mal ve işlenerek nihai mal olarak da kullanılmaktadır. Bundan dolayı petrol fiyatlarındaki dalgalanmalar dünya ekonomisi için oldukça önemlidir. Petrol fiyatlarındaki değişmeler özellikle petrole bağımlı olan ülkeleri fazlasıyla etkilemektedir. Petrol fiyatlarındaki artışlar petrol ihraç eden ülkeler açısından değerlendirildiğinde bu ülkelerde ekonomik büyümenin gerçekleştiği gözlemlenmiştir.

2016 y1lı itibari ile dünya petrol rezervi 1.706 milyar varildir. Dünyada en fazla petrol rezervine sahip olan bölge 813,5 milyar varil ile Ortadoğu olurken, bu bölgeyi 327,9 milyar varille Orta ve Güney Amerika izlemektedir. Ortadoğu'da günlük 31.789 milyon varil petrol üretilirken, Kuzey Amerika'da günlük 19.270 milyon varil petrol üretilmektedir. Dünya'da en fazla petrol rezervine sahip olan ülke ise 300,9 milyar varille Venezuela iken bu ülkeyi 266,5 milyar varille Suudi Arabistan takip etmektedir. Dünya'nın en büyük petrol üreticisi ülkesi günlük 12.354 milyon varille ABD olurken bu ülkeyi 12.349 milyon varille Suudi Arabistan izlemektedir. Bu iki ülkeyi, 11.227 milyon varille Rusya, 4.600 milyon varille İran, 4.465 milyon varille Irak, 4.073 milyon varille Birleşik Arap Emirlikleri, 3.999 milyon

varille Çin, 3.151 milyon varille Kuveyt, 2.605 milyon varille Brezilya, 2.456 milyon varille Meksika takip etmektedir. 2016 yllında Suudi Arabistan 585,7 milyon ton petrol üretimiyle ilk sırayı alırken, bu ülkeyi sırasıyla 554,3 milyon ton ile Rusya, 543 milyon ton ile ABD, 218,9 milyon ton ile Irak, 218,2 milyon ton ile Kanada, 216,4 milyon ton ile İran, 199,7 milyon ton ile Çin, 182,4 milyon ton ile Birleşik Arap Emirlikleri, 152,7 milyon ton ile Kuveyt, 136,7 milyon ton ile Brezilya, 124,1 milyon ton ile Venezuela, 121,4 milyon ton ile Meksika takip etmektedir (www.tespam.org, www.enerji.gov.tr ).

Dünya'nın en büyük petrol tüketicisi ülke konumundaki $\mathrm{ABD}$ günlük 19.631 milyon varil petrol tüketmektedir. $\mathrm{Bu}$ ülkeyi 12.381 milyon varille Çin takip etmektedir. ABD, 2016 yılında 863,1 milyon ton petrol tüketimi ile ilk sıray alırken, bu ülkeyi sırasıyla, 578,7 milyon ton ile Çin, 212,7 milyon ton ile Hindistan, 184,3 milyon ton ile Japonya, 167,9 milyon ton ile Suudi Arabistan, 148 milyon ton ile Rusya, 138,8 milyon ton ile Brezilya, 122,1 milyon ton ile Güney Kore, 113 milyon ton ile Almanya, 100,9 milyon ton ile Kanada, 83,8 milyon ton ile İran takip etmektedir. Türkiye, 41,2 milyon ton petrol tüketimi ile 23. sirada yer almaktadır. Dünya'nın en büyük petrol tüketici bölgesi ise Asya Pasifik’tir. Bölgede günlük 33.577 milyon varil petrol 
tüketilmektedir. Bu bölgeyi, günlük 23.843 milyon varille Kuzey Amerika izlemektedir

\section{(www.tespam.org).}

Petrol fiyatlarındaki dalgalanmalar ülkeler açısından önemli bir güç göstergesidir. Ekonomideki hemen hemen her sektör petrole bağımlı olduğundan dolayı, petrol fiyatlarında meydana gelen değişmeler ülkeleri yakından ilgilendirmektedir. Dalgalanmalar petrol ihraç eden ve ithal eden ülke ekonomilerini farklı şekilde etkilemektedir. Petrol fiyatlarındaki artışlar, petrol ithal eden ülkelerden petrol ihraç eden ülkelere doğru gelir transferi sağlamaktadır. Petrol ihraç eden ülke ekonomileri, petrol fiyatlarının yükselmesi sonucu ihracat gelir artışları ile reel gelirlerini petrol ithal eden ülkelerin tersine yükseltmektedirler. Petrol ithal eden ülkelerde ise bu durum enflasyona, cari açıklara, bütçe açıklarına neden olmaktadır. Fakat petrol talebinin fiyat esnekliğinin düşük olması petrol talebinde fazla azalmaya yol açmamaktadır. Hanehalkı açısından düşünüldüğünde petrol fiyatlarındaki artış reel geliri azaltan bir unsurdur. Dolayısıyla reel gelirin düşmesi yurtiçi talebi gerileterek ekonomik büyümeyi olumsuz yönde etkilemektedir.

Petrol fiyatlarının artması her ne kadar petrol ihraç eden ülkeleri olumlu yönde etkilese de uzun zamanda bu ülkeler olumsuz etkilenebilecektir. Çünkü, petrol fiyatlarının artmasından dolayı bu ülkelerde enflasyon yaşanacak ayrıca yüksek fiyat artışları dünyada alternatif enerji kaynağına sahip olan ülkelerin petrol ithalatını azaltarak petrol ihracatçısı ülkenin ihracat gelirini düşürecektir. Ulusal para birimleri aşırı değerlenecektir. Böylelikle ihracat azalacak ve ülkede dış açık oluşacaktır.

OPEC'in (Organization of the Petroleum Exporting Countries) 2015 yllinda net petrol ihraci 515 milyar \$ olurken, varil başına petrol 52 \$'dır. 2016 yılında petrol fiyatları varilbaşına 44 \$'a düşerken, net petrol ihracı 443 milyar \$ olmuştur. Petrol fiyatlarının 2017 yılında 60-65 \$ bandına çıkması beklenirken, varil başına petrol fiyatı ortalama olarak 64,41 \$'dan işlem görmektedir. OPEC'in 2017 yılı gelirlerinin 427 milyar \$ olacağını tahmin edilmektedir (www.opec.org ).

Çalışma, Ekonomik İşbirliği ve Kalkınma Örgütü’nün raporunda adı geçen Türkiye benzeri ülke olduğu kanaatine varılan ülkeler için yapılmıştır. Bu ülkeler Çin, Güney Afrika, Meksika, Kolombiya, Kosta Rika, Endonezya ve Kazakistan'dır. Ayrıca bu ülkelerin Türkiye gibi 2030 yılında yüksek gelirli ülkeler grubunda yer alması beklenmektedir.

\section{Literatür Taraması}

Literatürde çeşitli ülkeler için petrol fiyatları ile cari açık, reel milli gelir, enflasyon ve döviz kurları arasındaki ilişkiyi inceleyen çok sayıda çalışma yapılmıştır. Bunlardan bazıları kronolojik sıralama ile aşağıda verilmiştir.

1999 yılında Kibritçioğlu ve Kibritçioğlu'nun 1986-1998 yılları için VAR modeli kullanarak yaptığı çalışmaya göre, Türkiye'deki enflasyonda, petrol fiyat artış şoklarının diğer değişkenlerin şoklarından 50 kat daha büyük rol oynadığını ortaya konmuştur.

2006 yılında Karabulut ve Çelikel'in 1991-2004 dönemine ait verileri kullanarak VECM yöntemiyle yapmış olduğu çalışma sonucunda, petrol fiyatlarının cari açık üzerinde negatif etkisi olduğu sonucuna varılmıştır.
2007 yılında Zaovali'nin yaptı̆̆ çalıșmada, petrole olan talebin 2030 yılına kadar her yıl \%1,3 artacağı ve bu artışın Çin ve Hindistan'da yılda \%2,5 olacağını öngörerek petrol talebindeki \%70'lik bir artışın bu iki ülkeden kaynaklanacağ sonucuna varılmıştır. 2007 yılında Demirci ve Er, ham petrol fiyatlarının Türkiye'nin cari açığına etkilerini 1991-2006 dönem aralığında araştırmış ve sonuç olarak, petrol fiyatları ile cari açık arasında uzun dönemli ilişki olduğu sonucuna varmışlardır.

2008 yılında Ogenleye, yaptığı Natural Resources Abundance in Nigeria: From Dependence to Development adlı çalışmasında, Nijerya'nın petrol gelirleri ile ülkenin ekonomik büyümesi üzerindeki etkisini araştırmış ve sonuç olarak, petrol gelirlerinin özel tüketimi ve elektrik üretimini artırırken, tarım ve imalat sanayii üzerinde gerilemelere neden olduğundan dolayı ekonomik büyümeyi olumsuz etkilediğini ortaya koymuştur. 2008 yılındaColoni ve Manera'nın 1980-2003 yılları için VAR modeli kullanarak yaptıkları çalışma sonucunda, G7 ülkeleri için Japonya ve İngiltere hariç tüm ülkelerde petrol fiyatlarının enflasyon üzerindeki etkisinin olumsuz olduğu sonucuna ulaşılmıştır.

2009 yılında Mehrara'nın yaptığ $\breve{1}_{1}$ Reconsidering the Resource Curse in Oil-Exporting Countries adlı çalışmada, petrol ihraç eden ülkelere uyguladığı panel veri analizi sonucunda, petrol gelirlerindeki artışın ekonomiyi belli bir yere kadar pozitif etkilediği fakat belli bir yerden sonra bu etkinin negatif yöne çevrildiği sonucuna varılmıştır. 2009 yılında Demirbaş ve arkadaşlarının 1984-2008 yıllarına ait verileri ile VECM yöntemi kullanarak yaptığı çalışma sonucunda, petrol fiyatlarının cari açık üzerindeki etkisinin olumsuz olduğu sonucuna varılmıştır.

2010 yılında Özlale ve Pekkurnaz yaptıkları çalışmada, Türkiye'nin petrol fiyat değişimlerine karşı cari işlemler açığının kademeli olarak arttığı sonucuna ulaşırken, kısa dönemde petrol fiyatlarının Türkiye'nin cari işlemleri üzerinde anlamlı etkisinin olduğu sonucuna varmışlardır. 2010 yılında Du ve arkadaşlarının 1995-2008 dönemine ait verileri kullanarak VAR yöntemiyle yapmış oldukları çalışma sonucunda, dünya petrol fiyatlarının Çin'in makroekonomik aktiviteleri (gayri safi yurtiçi hasıla, enflasyon, para arzı ve faiz oranı) üzerinde etkisi olmakla birlikte, zayıf kaldığ edilmiştir.

2011 y1lında Iwayemi ve Fowowe, 1985-2007 dönemine ait verileri kullanarak ve VAR modeli ile petrol fiyatlarının Nijerya'nın birçok makroekonomik değişkeni (reel gayri safi yurtiçi hasıla, hükümet harcaması, enflasyon, reel döviz kuru, net ihracat) üzerinde çok büyük bir etkisinin olmadığı bulgusuna varmıştır.

2012 yılına Hassan ve Zaman'ın 1975-2010 dönemine ait verileri kullanarak yaptığı çalışma sonucunda, ARDL testi yapılmış ve petrol fiyatları, döviz kuru ve ticaret dengesi arasında anlamlı negatif bir ilişkinin olduğu sonucuna ulaşılmıştır. 2012 yılında Lebe ve Yaylalı'nın VAR modelini kullanarak yaptığı çalışmasında, 1986-2010 dönemi verileri kullanılmış ve petrol fiyatlarındaki artış enflasyonu artırmaktadır sonucuna ulaşılmıştır.

2013 yılında Yardımcıoğlu ve Gülmez'in yaptığı OPEC Ülkelerinde Hollanda Hastalığı: Petrol Fiyatları ve Ekonomik Büyüme İlişkisinin Ekonometrik Bir Analizi adlı çalışmada, 1970-2011 yılları arası dönemde 10 OPEC ülkesindeki petrol fiyatları ve ekonomik büyüme arasındaki ilişki incelenmiş 
olup, uzun dönemde petrol fiyatları ve büyüme oranları değişkenlerinin tek yönlü nedensellik ilişkisine dayandığ sonucuna varılmıştır.2013 yılında Lebe ve Akbaş'ın yapmış olduğu çalışma sonucunda, 1991-2012 verileri kullanılarak döviz kuru ve petrol fiyatlarından cari açığa doğru tek yönlü nedensellik ilişkisi olduğu ortaya konulmuştur. Ayrıca, cari açıkta meydana gelen artışların petrol fiyatları ile doğrudan etkisi olurken döviz kurunun da petrol fiyatları kadar olmasa da belli bir düzeyde cari açığı etkilediği tespit edilmiştir. Altıntaş'ın 2013 yaptığı çalışmada ise 1987-2010 dönemine ait veriler kullanılarak ARDL ve Nedensellik Testi yapılmış olup sonuç olarak, reel petrol fiyatının ihracat üzerindeki etkisini gösteren esneklik değeri pozitif ve anlamlı bulunmuştur. $\mathrm{Bu}$ sonuç incelenen dönemde petrol fiyatındaki artıştan ihracatın zarar görmediğini göstermiştir. 2013 yılında Bayat, Şahbaz ve Akçacı'nın yapmış olduğu çalışmada 19852012 yıllarına ait veriler kullanılarak Eşbütünleşme- Grenger Nedensellik Testi ile Türkiye'de orta vadede petrol fiyatlarındaki oynaklıklar diş ticaret açıklarının oluşmasında etkili iken, uzun vadede diş ticaret açıkları üzerindeki etkisi kaybolmaktadır sonucuna ulaşılmıştır.

2015 yılında Deniz ve Sümer'in Petrol Fiyatlarındaki Oynaklığın Dış Ticaret ve Milli Gelir Üzerindeki Etkisi'nin araştırıldığ düşüşün ülkelerde ciddi refah kayıplarına yol açtığı sonucuna ulaşılmıştır. 2015 yılında Yılmaz ve Altay’ın 1985-2015 yıllarını aldığı çalışmada ARDL Eşbütünleşme Yaklaşımı ile ham petrol fiyatlarının kur oynaklığı üzerindeki etkisinin negatif ve istatistiki olarak anlamlı olduğu sonucuna ulaşılmıştır. 2015 yılında Özdemir ve Ökgül'ün 2005-2014 yıllarını aldığı dönemde Markov Değişim Vektör Otoregresif (MS-VAR) Modelleri kullanılarak ham petrol ve benzin fiyatlarındaki değişimin sanayi üretimine etkisinin bu rejimlere bağlı olarak değiştiği bulunmuştur. Ayrıca petrol ve benzin fiyatlarının sanayi üretimine geçiş etkisi olduğu ortaya konulmuştur.

2016 yılında Demiral, Bal ve Akça'nın yaptığı Petrol Gelirleri ve Ekonomik Büyüme: Seçilmiş Petrol Zengini Gelişmekte Olan Ülkeler Üzerine Bir Panel Veri Analizi adlı çalışmada, aralarında Meksika ve Kazakistan'ın da bulunduğu ülkelerle ilgili olarak, kaynak zenginliğinin ülke ekonomik büyümeye katkı sağladığı fakat bu katkının yavaş olduğu yönündedir. Bu çalışmanın sonucuna göre, kişi başına reel gayri safi yurtiçi hâsıla ile ham petrol fiyatı, ham petrol ihracatı ve tüketici fiyat endeksi arasında pozitif, reel döviz kuru arasında ise negatifbir regresyon ilişkisi olduğu belirlenmiştir.2016 yılında Kaplan ve Aktaş'ın yaptığı çalışmada 1995-2014 yıllarını baz alarak yaptığı panel veri analizine göre, reel petrol fiyatlarındaki artış reel döviz kurunu pozitif yönde etkilemektedir sonucuna varılmıştır.

\section{Petrol Fiyatları İle Seçilen Ülkelerin Makro Değişkenleri Arasındaki İlişki}

Türkiye'de 2016 yılının ilk üç çeyreğinde cari açık azalış gösterse de son çeyrekte ülke ekonomisi \%1,8 küçülmüştür. $\mathrm{Bu}$ küçülmenin nedeni olarak petrol fiyatlarının artması gösterilebilir. Tabiki bu sadece nedenlerden bir tanesidir. Türkiye, 2015 y1lında 25 milyon 66 bin ton ham petrol ithal ederken bu rakam 2016 yılında 25 milyon ton olmuştur. Türkiye'nin 2016 yılı GSYH'si (Gayri Safi Yurtiçi Hasıla), 863 milyar \$'dır. Türkiye'nin ithalatı içerisinde petrolün payının oldukça fazla olması cari açığı olumsuz yönde etkilemektedir. Türkiye'nin 2016 y1lı toplam ithalatının \%3,9'unu petrol oluşturmaktadır. Türkiye 2016 yılında 7,34 milyar \$'lık petrol ithal etmiştir. Türkiye'nin petrol ithal ettiği ülkeler sırasıyla Irak, İran, Suudi Arabistan, Rusya ve Kuveyt'tir. Türkiye, petrole alternatif bulamadığından dolayı petrol fiyatları ülke için önem arz etmektedir. Petrol ithalatçısı ülke konumunda olan Türkiye için enerji ithalatı ilk sıradadır. Petrol fiyatlarındaki dalgalanmalar Türkiye gibi petrol ithal eden gelişmekte olan ülkelerin makroekonomik göstergeleri üzerinde etkili olmaktadır. İşlenmiş petrol, Türkiye'nin 2016 yılı ihracatının \%1,9'unu oluşmaktadır. Ülke, işlenmiş petrolden 2,65 milyar \$ gelir elde etmektedir. Türkiye'nin işlenmiş petrol ihraç ettiği ülkeler, Birleşik Arap Emirlikleri, Misır, Singapur, Suudi Arabistan'dır (https://atlas.media.mit.edu/tr/, $\quad$ http://www.enerji.gov.tr/trTR/Sayfalar/Petrol, www.tuik.gov.tr).

Güney Afrika'nın 2016 yılı ithalatı 74,7 milyar \$ olurken, ihracatı 74,1 milyar \$ olmuştur. Aynı yıl ülke, 6,5 milyar \$'lik ham petrol, 2,5 milyar \$'lik işlenmiş petrol ithal etmiştir. Ham petrol ithalatı toplam ithalatının \%8,9'unu, işlenmiş petrol ise $\% 3,5$ 'ini oluşturmatadır. Ülke petrol ihtiyacını çoğunlukla Orta Doğu ve Nijerya'dan karşılamaktadır. Güney Afrika petrol ihtiyacı açı̆̆ını kapatmak için ham petrolden sentetik yakıt üretimi yapmaktadır. Güney Afrika, sınırlı petrol kapasitesine rağmen kıtada Mısır'dan sonra ikinci sıraya yerleşmiştir. Ülke, 1,65 milyar \$'lık rafine petrol ihraç etmektedir. Toplam ihracatı içerisinde rafine petrolün payı $\% 2,4$ 'tür. Güney Afrika, rafine petrolün büyük çoğunluğunu Afrika ülkelerine satmaktadır. 2016 yılında Güney Afrika'nın GSYH'si (Gayri Safi Yurtiçi Hasıla) 294,8 milyar\$ olmuştur (https://atlas.media.mit.edu/tr, http://www.worldbank.org/tr ).

Çin, ABD'den sonra dünyada ikinci büyük ekonomi konumundadır. Çin'in 2016 yılı GSYH'si (Gayri Safi Yurtiçi Hasıla)11,2 trilyon \$'dır. Çin, 117 milyar \$'lık petrol ithal ederken, 19,3 milyar \$'lık petrol ihraç etmektedir. Ülkenin toplam ithalatında petrolün payı \%8,8 olurken, ihracındaki pay \%0,94 olmuştur. Ülke, ham petrol ithal edip işlenmiş petrol ihraç etmektedir. Petrol ihraç ettiği ülkeler arasında Singapur, Honkong, Filipinler, Amerika ve Avusturulya vardır. Çin, petrol ihtiyacının büyük bir kısmını İran'dan karşılamaktadır. Bunun yanı sıra, Suudi Arabistan, Irak ve Rusya'dan da petrol ithal etmektedir. Ülke, 2016 yılında rekor kırarak 381 milyon ton petrol ithal etmiştir. Çin, ABD yaptırımlarından etkilenmemek adına petrol ithal ederken dolar yerine altına çevrilebilir yuan kontratları kullanacaktır (https://atlas.media.mit.edu/tr, http://www.worldbank.org/tr ).

Dünya'nın 7. büyük petrol şirketi PEMEX Meksika'da faaliyet göstermektedir. Ülke, 2016 y1lında elde ettiği ihracat gelirlerinin \%5'ini petrolden kazanmıştır. 2016 yılında Meksika'nın GSYH'si (Gayri Safi Yurtiçi Hasıla) 1,046 trilyon \$ olmuştur. Ülke, 15,5 milyar \$ 'lik ham petrol ihraç ederken, 18 milyar \$ lik işlenmiş petrol ithal etmektedir. Ham petrol ihraç ettiği ülkeler arasında, Amerika, İspanya, Hindistan, Japonya; işlenmiş petrol ithal ettiği ülkeler arasında ise Amerika, Hollanda, İspanya ve Singapur yer almaktadır. Ülkenin toplam ithalatında petrolün payı \% 4,7 olurken, toplam ihracatındaki payı \%4.1 olarak gerçekleşmiştir(https://atlas.media.mit.edu/tr, http://www.worldbank.org/tr).

Kolombiya'nın 2016 yılındaki GSYH'si (Gayri Safi Yurtiçi Hasıla) 282,5 milyar \$ olmuştur. Ülkenin 
ihracatındaki en büyük payı $\% 25,8$ 'lik bir payla ham petrol almaktadır. Ham petrol geliri 7,87 milyar \$ olurken, rafine petrol ihracı 1,96 milyar \$ olmuştur. Rafine petrolün ülkenin toplam ihracındaki payı \%6,5 olmuştur. Kolombiya, ham petrolü, Amerika, Panama, Çin ve İspanya'ya ihraç ederken; işlenmiş petrolü, Amerika, Bonaire, Gibraltar, İspanya ve Panama'ya ihraç etmektedir. Ülke aynı yıl \%8,2'lik bir payla işlenmiş petrol ürünleri ithal etmiştir. Petrolün toplam ithalattaki payı 2016 yılında 3,51 milyar \$ olmuştur. Petrol ithal ettiği ülkeler arasında, Amerika, Meksika, Hollanda ve İngiltere yer almaktadir (https://atlas.media.mit.edu/trhttp://www.worldbank.org/tr ).

Kosta Rika'nın 2016 yılındaki GSYH'si (Gayri Safi Yurtiçi Hasıla) 57,44 milyar \$ olmuştur. Ülke, ithalatının büyük bir kısmını ABD, Çin ve Meksika'dan sağlamaktadır. Kosta Rika, 2016 yılında 1,09 milyar \$'lık işlenmiş petrol ithal ederken 2,7 milyon \$'lık petrol ihraç etmiştir. Petrolün toplam ithalattaki payı $\% 7,4$ olurken, ihracattaki payı ise \%0,02 olmuştur. Kosta Rika'nın petrol ithal ettiği ülkeler arasında, Amerika, Belçika, Panama, Meksika ve İspanya yer alırken; petrol ihraç ettiği ülkeler arasında Panama, Nicaragua, Guatemala ve Honduras yer almaktadır. (https://atlas.media.mit.edu/tr, http://www.worldbank.org/tr ).

Endonezya'nın 2016 yılındaki GSYH'si (Gayri Safi Yurtiçi Hasıla) 932,3 milyar \$ olmuştur. Endonezya, 6,7 milyar \$'lik ham petrol ithal etmektedir. Ham petrol ithalat toplam ithalatının \%5,1'ini oluşturmaktadır. Ülke aynı yıl 9,9 milyar \$'llk işlenmiş petrol ithal etmiş ve toplam ithalatında işlenmiş petrolün pay1 \% 7,5 olmuştur. Endonezya, ithalatı en çok Çin, Singapur ve Japonya'dan yapmaktadır. Endonezya, ham petrolden 2016 yilında 4,3 milyar \$ gelir elde ederken, toplam ihracatında petrolün payı \%3,5 olmuştur. Ülkenin ham petrol ihraç ettiği ülkeler arasında, Japonya, Tayland, Çin, Malezya, Singapur, Amerika ve Avusturalya yer almaktadir(https://atlas.media.mit.edu/tr,

http://www.worldbank.org/tr ).

Kazakistan'ın 2016 yılındaki GSYH'si (Gayri Safi Yurtiçi Hasıla) 133,7 milyar \$`dır. Ülke, petrol ithalatının büyük bir kısmını Rusya'dan sağlamaktadır. Petrol ithalatı toplam ithalatının \%3,1'ini oluşturmaktadır. Ülke aynı yıl 777 milyon \$'lik rafine petrol ithal etmiştir. Petrol ithal ettiği ülkeler arasında, Rusya, Kırgazistan, Almanya, İtalya ve Finlandiya yer almaktadır. Ülke, 2016 yılında 19,4 milyar \$'lık ham petrol ihraç ederken, 813 milyon \$'lık rafine petrol ihraç etmiştir. Toplam ihracatının içinde ham petrolün payı $\% 53$ olurken, rafine petrolün payı ise \%2,2 olmuştur. Kazakistan'ın petrol ihraç ettiği ülkeler arasında, Hollanda, İtalya, İsviçre, Fransa, Çin ve Portekiz yer almaktadır (https://atlas.media.mit.edu/tr ,http://www.worldbank.org/tr) .
Tablo 1: Seçili Ülkelerin Makroekonomik Göstergeleri

\begin{tabular}{|c|c|c|c|c|c|c|}
\hline YILLAR & $\mathbf{2 0 1 5}$ & $\mathbf{2 0 1 6}$ & $\mathbf{2 0 1 5}$ & $\mathbf{2 0 1 6}$ & $\mathbf{2 0 1 5}$ & $\mathbf{2 0 1 6}$ \\
\hline ÜLKELER & \multicolumn{2}{|c|}{$\begin{array}{c}\text { Petrol Fiyatları } \\
\text { (varil başına \$) }\end{array}$} & \multicolumn{2}{|c|}{\begin{tabular}{l}
\multicolumn{2}{|c|}{ Enflasyon \% } \\
Cari Açık \\
(Milyar \$)
\end{tabular}} \\
\hline TÜRKIYYE & 52 & 44 & 7,6 & 7,7 & $-32,11$ & $-32,62$ \\
\hline ÇİN & 52 & 44 & 1,4 & 2,0 & 304,16 & 196,38 \\
\hline KAZAKİSTAN & 52 & 44 & 6,6 & 8,5 & $-5,46$ & $-8,50$ \\
\hline MEKSİKA & 52 & 44 & 2,7 & 2,8 & $-33,34$ & $-27,85$ \\
\hline ENDONEZYA & 52 & 44 & 6,3 & 3,5 & $-17,51$ & $-16,34$ \\
\hline KOSTA RIKA & 52 & 44 & 0,7 & 0,0 & $-2,38$ & $-1,87$ \\
\hline KOLOMBIYYA & 52 & 44 & 5,0 & 7,5 & $-18,78$ & $-12,54$ \\
\hline $\begin{array}{c}\text { GÜNEY } \\
\text { AFRIKA }\end{array}$ & 52 & 44 & 4,5 & 6,3 & $-13,91$ & $-9,47$ \\
\hline
\end{tabular}

Kaynak: Yazarlar tarafindan derlenmiştir.

Tablo 1'de seçili ülkelerin 2015-2016 yıllarına ait petrol fiyatları, cari açık ve enflasyon oranlarına yer verilmiştir. OPEC tarafından belirlenen petrol fiyatları bütün ülkeler için aynı alınmıştır. 2015 yılında varil başına petrol fiyatı 52 \$ olurken, 2016 yılında 44 \$ olmuştur. 2015 ve 2016 y1lları için Çin hariç diğer seçili ülkeler cari açık vermişlerdir. Aynı yıllarda Endonezya ve Kosta Rika haricindeki ülkelerin enflasyon oranları artış göstermiştir.

\section{Veri Seti ve Ekonometrik Metodoloji}

Çalışmada Ekonomik İşbirliği ve Kalkınma Örgütü'nün 12 Aralık 2016 tarihli “Küresel Kalkınma Hakkında

Perspektifler 2017-Değişen Dünyada Uluslararası Göç" adıyla yayınlanan raporda adı geçen Türkiye, Çin, Güney Afrika, Meksika, Kolombiya, Kosta Rika, Endonezya ve

Kazakistan gibi gelişmekte olan 8 ülkenin cari açık ve enflasyon değişkenleri için, 1980 - 2016 yıllarını kapsayacak şekilde oluşturulan dengeli panel veri seti kullanılmıştır. Bu veri setinde yer alan değişkenler üzerinde Küresel Piyasalar Brent Ham Petrol Fiyat değişimlerinin etkisi incelenmiştir.

Tablo 2: Seçili Ülkelerin Panel Verileri

\begin{tabular}{|l|l|}
\hline Değişken Kodu & \multicolumn{1}{|c|}{ Açıklama } \\
\hline CAB & Bütçe Dengesi ( Amerikan Doları ) \\
\hline INF & Enflasyon (Tüketici Fiyatları Yıllık \%) \\
\hline BCOILUSD & $\begin{array}{l}\text { Küresel Piyasalar Brent Ham Petrol Fiyatı (Varil } \\
\text { Amerikan Doları) }\end{array}$ \\
\hline
\end{tabular}

Kaynak: http://databank.worldbank.org/data/databases.aspx

Petrol fiyatları ilişkileri panel veri teknikleri kullanılarak analiz edilmiştir. Aşağıda verilen yöntemler analiz için SAS/ETS(R) 9.3 programında ayrı ayrı etkileri araştırmak amacı ile hesaplanmıştır.

\section{- $\quad$ Sabit Etkiler Modeli (FixedEffects Model)}

- Rassal Etkiler Modeli ( RandomEffects model)

- Genelleştirilmiş Momentler Metodu (GMM).

- Panel Devingen Olağan En Küçük Kareler Yöntemi (Pooled OLS)

Zaman serisi ve yatay kesit verilerini birlikte ele alan panel veri analizinde uygun görülen lineer ekonometrik modelleri sınama yolu ile ham petrol fiyat değişimi ile diğer göstergeler arasındaki ekonomik ilişkiyi en iyi açıklayan eşitliklere ve tahmin yöntemlerine ulaşılmaya çalışılmıştır. Ayrıca doğrusal modelin varsayımları ile ilgili olarak şans değişkeninin ortalaması sıfır, varyansının sabit (homojen) ve kovaryansları sıfırdır (Y. İşyar,1999). Modellerin 
spesifikasyonunda hemoskedastisite varsayımının ihlal edilmemesi hedeflenmiştir.

Yukarıda listelenen yöntemler ile elde edilen sonuçlar, analiz edilen ilişkilerdeki değişkenlere ait verisetine göre, hata teriminin yapısı dikkate alınarak mukayese edilmiştir. Hata teriminin yapısına uygun görülen modeller arasında sapmasız, etkin, yeterli ve tutarlı tahminciler elde etmek üzere ilerlenmiştir.

Buna göre; rassal etkiler modellerinin sınanması için Hausman Spesifikasyon Testi sonuçları dikkate alınmıştır. Test sonuçları hata teriminin regresörler ile korele olmadığına işaret etmektedir. Rassal etkilerin varlığını istatistiksel olarak doğrulamaktadır. Tahminlerin etkin ve tutarlı olması beklenir. Ancak $R^{2}$, Determinasyon Katsayısı \%13 hesaplanmıştır ve modelin açıklayıcılığı yeterli görülmediğinden spesifikasyonu tercih edilmemiştir.

Sabit etkiler modeli için elde $\mathrm{F}$ istatistikleri test edildiğinde sabit etkilerin bulunmadığını desteklenmektedir. Bu durumda "Olağan En Küçük Kareler" tahmincisinin etkin sonuçlar vermesi beklenmemektedir.

Tahmin modeli dinamik olduğundan, sabit etki yöntemi (fixedeffects) asimptotik olarak yanlı sonuçlar vermektedir (Nickell, 1981). Bunu düzeltmek ve olası içsellik problemini azaltmak için, bağımsız değişkenin gecikmeli değerleri enstrüman olarak kullanılabilir. $\mathrm{Bu}$ bağlamda, klasik enstrüman yöntemlerinden daha etkin (efficient) sonuçlar veren Arellano-Bover (1995) ve Blundell- Bond (1998) sistem genelleştirilmiş momentler metodu (GMM) kullanılmıştır. Ancak, sistem GMM metodu, T arttıkça enstrüman çokluluğu (instrumentproliferation) problemine sahiptir. $\mathrm{Bu}$ problem, içsel değişkenlerin aşırı teşhis edilmesine (overidentifying), katsayı tahminlerinin enstrüman-dışı tahminlere yakınsamasına ve bu bağlamda sapmalı olmasına yol açabilmektedir (Arellano, 2003). Ayrıca, gereğinden fazlasayıda enstrüman kullanımı, GMM yönteminin standart hata tahminlerinin aşağı yönlü yanlı (downwardbias) olmasına sebep olabilmektedir. Dolayısıyla, tahminlerimizi alırken, enstrüman sayısı kısıtlı tutulmuştur. Genelleştirilmiş momentler metodu ve iterasyonları için SarganไHansen Testi aşırı teşhis edilme durumu için uygulanmıştır.

$H_{0}$ : Aşırı teşhis edilme durumu için kısıtlamalar geçerlidir.

$H_{1}$ : Aşırı teşhis edilme durumu için kısıtlamalar geçersizdir.

Test sonuçlarında H0 red edilememiş ve müsbet sonuç vermiştir.

Tablo 3: Parametre Tahminleri

\begin{tabular}{|c|c|c|c|c|c|c|}
\hline \multicolumn{7}{|c|}{ Parametre Tahminleri } \\
\hline Endojen Değişken & Egzojen Değişken & SD & Tahmin & Standart Hata & $\mathbf{t}$ & $\operatorname{Pr}>|\mathbf{t}|$ \\
\hline Kesme Terimi & Kesme Terimi & 1 & 112021634.89 & 202130000.00 & 0.55 & 0.58 \\
\hline Cari Denge & BCOILUSD & 1 & -30833384.19 & 5709105.00 & -5.40 & $<.0001$ \\
\hline Kesme Terimi & Kesme Terimi & 1 & 2.44 & 0.54 & 4.50 & $<.0001$ \\
\hline Enflasyon & BCOILUSD & 1 & 0.04 & 0.01 & 4.68 & $<.0001$ \\
\hline
\end{tabular}

Kaynak:SAS/ETS(R) 9.3 Proc Panel Prosedürü sonuçlarından derlenmiştir

\section{Amprik Bulgular}

Modellerin spesifikasyonu için yapılan karşılaştırmalar sonucunda değişkenler arasındaki ilişkiyi açıklamak için kullanılan yöntemler Genelleştirilmiş Momentler Metodu ve iterasyonudur. Tüm model spesifikasyonunda bağımsız değişken Brent Ham Petrol fiyatıdır. Petrol fiyatı bağımlı değişkenler üzerine regres edilmiştir.

Tablo 3'te Genelleştirilmiş Momentler Metodu ve iterasyonları ile hesaplanan Kesme Terimi ve Parametre tahminleri her bir eşitlik için ayrı ayrı yer verilmiştir. $\operatorname{Pr}>|t|$ için verilen olasılık değerleri eşitliklerin parametre tahminlerinin istatistiksel olarak anlamlı bir biçiminde sıfırdan farklı olduğuna işaret etmektedir.

\section{Sonuç}

Ekonomik İşbirliği ve Kalkınma Örgütü’nün (OECD) 12 Aralık 2016 tarihli 'Küresel Kalkınma Hakkında Perspektifler 2017-Değişen Dünyada Uluslararası Göç” adıyla yayınlanan raporda adı geçen Türkiye ve benzeri ülkeler olan Çin, Güney Afrika, Meksika, Kolombiya, Kosta Rika, Endonezya ve Kazakistan'ın, 2030 yılında yüksek gelirli ülkeler grubunda yer almasının gösterilmesi üzerine yapılan çalışmada ulaşılan sonuçlara göre,

Enflasyon ve petrol fiyatlari:

$$
I N F_{i}=\beta_{1 i}+\beta_{2 i}^{*} \text { BCOILUSD }+\varepsilon_{i}
$$

eşitliği ile açıklanan bağımlı değişken enflasyon ve bağımsız değişken petrol fiyatları arasında genelleştirilmiş momentler metodu iterasyonu ile hesaplanan ilişki pozitif yönlüdür. Buna göre, ham petrol fiyatında bir dolar artış, incelenen ülkeler genelinde enflasyon üzerine $\% 0.04$ artışa sebep olmaktadir.

Cari denge ve petrol fiyatları:

$$
C A B_{i}=\phi_{1 i}+\phi_{2 i} * B C O I L U S D+v_{i}
$$

genelleştirilmiş momentler metodu iterasyonu ile hesaplanan tahminci katsayısı negatif olarak bulunmuştur. $\mathrm{Bu}$ durum apriori bilgi ve ekonomik teoriye göre beklentimize uygundur. Buna göre, ham petrol fiyatında artış cari denge üzerinde negatif bir etki yaparak cari açık yönünde tesir etmektedir. Petrol fiyatında bir birim artış, cari denge üzerinde-\$30.833.384,19 etki yaratmaktadır.

\section{Kaynaklar}

Altıntaş, H. (2013). “Türkiye'de Petrol Fiyatları, İhracat Ve Reel Döviz Kuru İlişkisi: Ardl Sınır Testi Yaklaşımı Ve Dinamik Nedensellik Analizi', Uluslararası Yönetim İktisat ve İşletme Dergisi, Cilt 9, Sayı 19.

Anam Hassan, S., Zaman, K., (2012), Effect of oil prices on trade balance: New insights into the cointegration relationship from Pakistan. Economic Modelling, 29, 2125-2143. 
Aydoğu, İ. (2006). "Küresel Ekonomik Gelişmeler ve Türkiye", Afyon Kocatepe Üniversitesi B.F. Dergisi, Cilt 8 , Say1 2.19-52.

Bayat, T., Şahbaz, A., Akçacı, T., (2013), "Petrol Fiyatlarının Dış Ticaret Açığı Üzerindeki Etkisi: Türkiye Örneği', Erciyes Üniversitesi İIBF Dergisi, Say1 42, 67-90.

Bayraç, N., "Uluslararası Petrol Piyasasının Ekonomik Analizi', 1-24.

BP Dünya Enerji İstatistikleri Raporu.2017

Cologni, A., Manera, M., (2008). “Oil prices, inflation and interest rates in a structural cointegrated var model for the G-7 countries', Energy Economics, 30, 856-888.

Demiral, M.,Bal, H.,Akça.E.E., (2016), "Petrol Gelirleri ve Ekonomik Büyüme: Seçilmiş Petrol Zengini Gelişmekte Olan Ülkeler Üzerine Bir Panel Veri Analizi', Sosyoekonomi, Vol (24)27, 85-102.

Demirbaş, M.,Türkay, H. ve Türkoğlu, M. (2009), "Petrol Fiyatlarındaki ,Gelişmeleri Türkiye'nin Cari Açığı Üzerine Etkisinin Analizi', Süleyman Demirel Üniversitesi İIBF Dergisi, 14(3), 289-299.

Demirci, E., Er, Ş., (2007), "Ham Petrol Fiyatlarının Türkiye'deki cari açığa Etkisinin İncelenmesi', 8. Türkiye Ekonometri ve İstatistik Ulusal Kongresi, 24-25 Mayıs, İnönü Üniversitesi, Malatya.

Deniz, M. Sümer, K. (2015), "Petrol Fiyatlarındaki Oynaklığın Dış Ticaret ve Milli Gelir

Üzerindeki Etkisi: Seçilmiş Bazı Avrasya Ekonomileri Üzerine Bir İnceleme', Internaional Conference on Eurasian Economies 2015, 298-304.

Dış Ekonomik İlişkiler Kurulu, Güney Afrika Ülke Bülteni, 2017.

Du, L., He, Y., Wei, C., (2010), "The Relationship Between Oil Price Shocks and China's Macroeconomics: An Empricial Analysis', Energy Policy, 38(8), 4142-4151.

Hacıŏlu, M., Sümer, K, K. (2015). "Petrol Fiyatlarındaki Oynaklığın Diş Ticaret ve Milli Gelir Üzerindeki Etkisi: Seçilmiş Bazı Avrasya Ekonomileri Üzerine Bir İnceleme', International Conference on Eurasian Economies, 298-304.

Iwayemi, A., Fowowe. B., (2011), "Impact of Oil Price Shocks on Selected Macroeconomic Variables in Nigeria', Energy Policy, 39(2), 603-612.

Kaplan, F., Aktaş, A., (2016), "Petrol Bağımlısı Ülkelerde Reel Petrol Fiyatlarının Reel Döviz Kuruna Etkisi', Business and Economics Research Journal, 7(2),103-113.

Karabulut, G., Çelikel Danışoğlu, A., (2006), “Türkiye'de Cari İşlemler Açığının Büyümesini Etkileyen Faktörler', Gazi Üniversitesi İ̇BF Dergisi, 8(1), 47-63.

Kibritçioğlu, A., Kibritçioğlu, B. (1999), "Ham Petrol ve Akaryakıt Ürünü Fiyat Artışlarının Türkiye'deki Enflasyonist Etkileri', Hazine Müsteşarlığı1, 1-73.

KOOROS, S. K., SUSSAN, A. P. \& SEMETESY, M. (2006). "The Impact Of Oil Prices On Employment", International Research Journal of Finance and Economics, 6(5),136-154.
Korhonen, L. A, \& Ledyaeva, S. (2010). “ Trade Linkages And Macroeconomic Effects Of The Price Of Oil',, Energy Economics, 32, 848-856.

Lebe, F., Akbaş, Y. (2013), "İthal Ham Petrol Fiyatları İle Döviz Kurunun Cari Açık Üzerindeki Etkisi: Türkiye İçin Bir Araştırma', EconAnadolu 2013 Anadolu Uluslararası İktisat Kongresi, Eskişehir,172-197.

Mehrara, M. (2009), "Reconsidering the Resource Curse in Oil-Exporting Countries", Energy Policy, 37(3), 11651169.

Ogunleye, E.K. (2008), "Natural Resources Abundance in Nigeria: From Dependence to Development", Resources Policy, 33(3), 168-174.

Orsam (Ortadoğu Stratejik Araştırmalar Merkezi), (2014), Petrol Fiyatlarındaki Düşüş Ve Ortadoğu Ekonomilerine Etkileri, 2014 Aralık Raporu. Rapor No:194.

Özdemir, S., Akgül, I., (2015), "Ham Petrol ve Benzin Fiyatlarının Sanayi ÜretimineEtkisi: MS-VAR Modelleri ile Analizi', Ege Akademik Bakış Dergisi, 15(3), 367-378.

Özlale, Ü., Pekkurnaz, D. (2010), “Oil Prices and Current Account: A Strucural Analysis for the Turkish Economy, Energy Policy, 38(8), 4489-4496.

Türkiye Petrollleri 2016 Yılı Ham Petrol ve Doğal Gaz Sektör Raporu.

Yardımcıŏlu, F., Gülmez, A., (2013), “OPEC Ülkelerinde Hollanda Hastalığı: Petrol Fiyatları ve Ekonomik Büyüme İlişkisinin Ekonometrik Bir Analizi”, Sosyoekonomi, 2013(1), 117-140.

Yaylal1, M., Lebe, F. (2012), “İthal Ham Petrol Fiyatlarının Türkiye'deki Makroekonomik Aktiviteler Üzerindeki Etkisi', Marmara Üniversitesi İIBF Dergisi, XXXII(2), 43-68.

Yılmaz, A., Altay, H., (2015), "İthal Ham Petrol Fiyatları ve Döviz Kuru Arasındaki Eşbütünleşme ve Oynaklık Yayılma Etkisinin İncelenmesi: Türkiye Örneği'”, Ege Akademik Bakış Dergisi, 16(4), 655-671.

Zaouali, S. (2007). "Impact Of Higher Oil Prices On”, The Chinese Economy Review, 31(2), 191-214.

http://www.enerji.gov.tr/tr-TR/Sayfalar/Petrol ( Son Erişim Tarihi: 10.10.2017)

http://www.keepeek.com/Digital-Asset-

Management/oecd/development/perspectives-on globaldevelopment-2017 persp_glob_dev-2017en\#.Wdpj0miOPIU\#page1 (Son Erişim Tarihi 15.10.2017)

www.ekonomi.gov.tr (Son Erişim Tarihi: 29.10.2017)

www.gtb.gov.tr (Son Erişim Tarihi:05.11.2017)

www.atlas.media.mit.edu (Son Erişim Tarihi:

$05.11 .2017)$

www.tradingeconomics.com (Son Erişim Tarihi: 05.11.2017)

http://www.opec.org/opec_web/static_files_project/med ia/downloads/publications/AR\%202016.pdf (Son Erişim Tarihi: 05.11.2017)

http://www.opec.org/opec_web/en/data_graphs/40.htm (Son Erişim Tarihi:05.11.2017)

http://www.worldbank.org/tr/country/turkey(Son Erişim Tarihi:05.11.2017) 
www.tuik.gov.tr (Son Erişim Tarihi:05.11.2017)

https://atlas.media.mit.edu/tr/profile/country/tur/(Son

Erişim Tarihi:05.11.2017)

https://atlas.media.mit.edu/tr/profile/country/kaz/(Son

Erişim Tarihi:05.11.2017)

https://atlas.media.mit.edu/tr/profile/country/idn/(Son

Erişim Tarihi:05.11.2017)

https://atlas.media.mit.edu/tr/profile/country/cri/(Son

Erişim Tarihi:05.11.2017)

https://atlas.media.mit.edu/tr/profile/country/col/(Son

Erişim Tarihi:05.11.2017)
https://atlas.media.mit.edu/tr/profile/country/chn/(Son Erişim Tarihi:05.11.2017)

https://atlas.media.mit.edu/tr/profile/country/me/(Son Erişim Tarihi:05.11.2017)

https://atlas.media.mit.edu/tr/profile/country/zaf/(Son Erişim Tarihi:05.11.2017)

https://www.tespam.org/2017-bp-dunya-enerjiistatistikleri-raporu/ (Son Erişim Tarihi:05.11.2017) 